\title{
AN INTELLIGENT ENERGY MANAGEMENT SYSTEM FOR SHIP HYBRID POWER SYSTEM BASED ON RENEWABLE ENERGY RESOURCES
}

\author{
Mohab Gaber ${ }^{1}$, S.H. El-banna², M.S. Hamad ${ }^{3}$, Mahmoud El-Dabah ${ }^{2}$ \\ ${ }^{1}$ R\&D Department, Egyptian Navy, Alexandria, Egypt. \\ ${ }^{2}$ Electric Engineering Dept., Faculty of Engineering, Al-Azhar University, Cairo, Egypt. \\ ${ }^{3}$ Arab Academy for Science and technology and maritime Transportation, Alexandria, Egypt. \\ *Corresponding Author E-mail: mohab_gaber@ieee.org
}

\begin{abstract}
A hybrid ship power system with fuel cell and storage system batteries/supercapacitors can be developed by adding renewable energy sources. Adding PV to the hybrid system enhances the system's reliability and dependability. However, a high-level control strategy is needed to manage the generated power between the fuel cell and the photovoltaic array and determine the suitable time to charge or discharge the stored energy according to the load demand. The perfect solution is using an intelligent neural network technique to control the ship's hybrid power system because of the system's nonlinearity and the existence of pulsing and highdensity load demand. This paper introduces an intelligent artificial neural network (ANN) technique that depends on previous experience. ANN is flexible and easy to modify, adding/removing power system components, and be scaled to any ship power system rating. Simulation results using MATLAB software prove that the robust, intelligent power management system can control and identify which energy source will be exploited according to the daylight.
\end{abstract}

Moreover, calculate the amount of generating power depending on the shipload demand. In addition to that, it ensures the system dependability considering the other source as standby while the storage system is the power source in the transient period in case of switching between the two systems and maintaining the storage system in the high state of charge possible. Furthermore, this will reduce fuel consumption during the ship's cursing mission.

KEYWORDS: Renewable energy, fuel cell, solar energy, intelligent control, all-electric ship, ship power system, daylight, storage system neural network. 


$$
\begin{aligned}
& \text { نظام نكى لإدارة نظام طاقه كهربيه هجين لسفينه إعتماداً على مصادر طاقه متجددة. } \\
& \text { مهاب جابر "*، سيد حسنى البنا" ، مصطفى سعد حمد” ، محمود الاباح" } \\
& \text { مركز البحوث , القوات البحريه, الأسكندريه , مصر } \\
& \text { قسم الهندسه الكهربيه, كلية الهندسة , جامعة الازهر, القاهرة , مصر } \\
& \text { الأكاديميه العربيه للعلوم و التكنولوجيا و النقل البحرى, الاسكندريه , مصر هر هريه }
\end{aligned}
$$

E-mail:- mohab gaber@ieee.org البريد الاليكتروني للباحث الرئيسى:

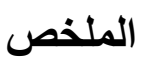

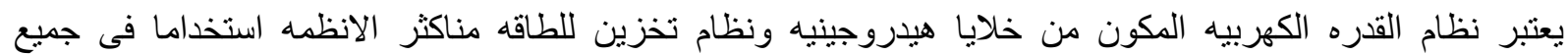

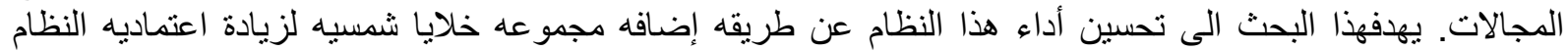

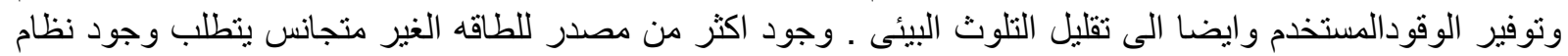

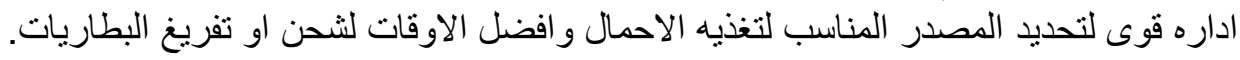

يقدم البحث نظام اداره الطاقه الذكى باستخدام تقنيه الثبكات العصبونيه و الذى يتميز بالمرونه و القدره على التكيف اعتمادا

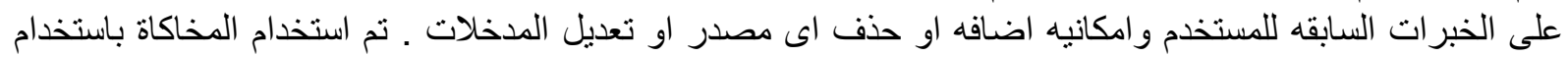

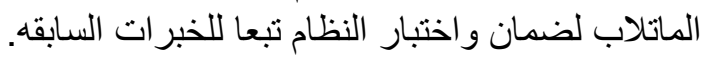

الكلمات المفتاحية :الطاقه المتجددة, خلايا هيدروجينيه, خلايا شمسيه,رنظام تحكم ذكى, نظام كهربي موحد للسفن , الاسضاءه اليوميه , نظام تخزين الطاقه , الثبكه العصبونيه.

\section{INTRODUCTION}

After the Paris agreement under the United Nations Framework, shipbuilders had gone vastly toward reducing the emission gases from ships, International Marine Organization (IMO) initial Green Houses Gas (GHG) strategy to accelerate the decarburization efforts in the shipbuilding industry[1]. The electric ship was a perfect solution to reduce GHG by electrification the ship equipment [2]. Navy ship has been developed all-electric ships (AES) techniques, allowing all ships' loads propulsion system and service loads to be powered from the same power supply[3]. All-Electric Ships allows reducing greenhouse emissions and shifting toward a broad increase in utilizing renewable and sustainable energy in naval ships[4]. The naval ship takes the opportunity to develop in this field. The naval ship has several types of loads, not only the propulsion system loads but also the weapon, sensors load. The electrification for all ship systems needs an integrated power system (IPS) to integrate. An artificial intelligent control technique is proposed to manage and control the ship electric power system with non-homogeneous power sources. [5, 6].

Early to mid-1980s, Artificial Intelligence (AI.) provides solutions to complex problems in power system engineering was tough and tedious[7]. However, the Hybrid renewable energy system is bright up as the wide using renewable energy due to the existing several nonhomogeneous energy sources in the system and the power sources like fuel cell, solar energy, and sometimes diesel engine and storage energy the battery or supercapacitor.

Hybrid systems use to overcome the drawback of the slow response of some sources like a fuel cell or the absence of the resources like solar energy during blackness and the physical 
characteristic of storing systems like heavy and increase the cost. All these factors lead to using a hybrid power system to benefit each design and overcome its drawback.

These ship's hybrid power systems can be considered traction systems needed control and management strategy [8]. These strategies according to the vehicle applications $[9,10]$. A new trend is present as Autonomous Vehicles[11]. Fuzzy logic is used to controller real-time design of a power management strategy for a hybrid electric traction system to protect the storage battery from overcharging during the repetitive braking energy accumulation[12]. Artificial neural networks (ANN) and machine learning protect the fault in a shipboard on a shipboard power system[13, 14]. Adaptive neuro-fuzzy technique ANFIS used to control the hybrid system's strategy consists of the fuel cell, P.V., and wind energy [15, 16].

\section{SHIP MICROGRID MANAGEMENT AND CONTROL.}

During overseas cruising, the ship's electrical power system is considered an island microgrid. However, when connected to shore power, the same power system acts as a grid-connected microgrid or an extension of the grid [17]. Nowadays, these conventional tenets obligatory for replacement by clean energy sources such as wind, solar, and fuel cells [18, 19]. Therefore, the U.S. Navy has changed its priority from installing systems with high capabilities to more affordable systems and enabling them to integrate with each other's to get the best performance.

The new generation of commercial and warships is characterized by an integrated power system (IPS). This system incorporates all power sources to provide the provide power and feed shipboard electric loads. This is the All-Electric Ship technique. Renewable energy, power generation, power electronics, and energy storage systems with suitable communication protocol controlled with intelligent control systems necessitate real-time power management and power system reconfiguration, especially in equipment failure and battle damage situations. This is the new revolution in marine and naval ship microgrids [17].

The integrated power architecture provides the framework for partitioning the equipment and software

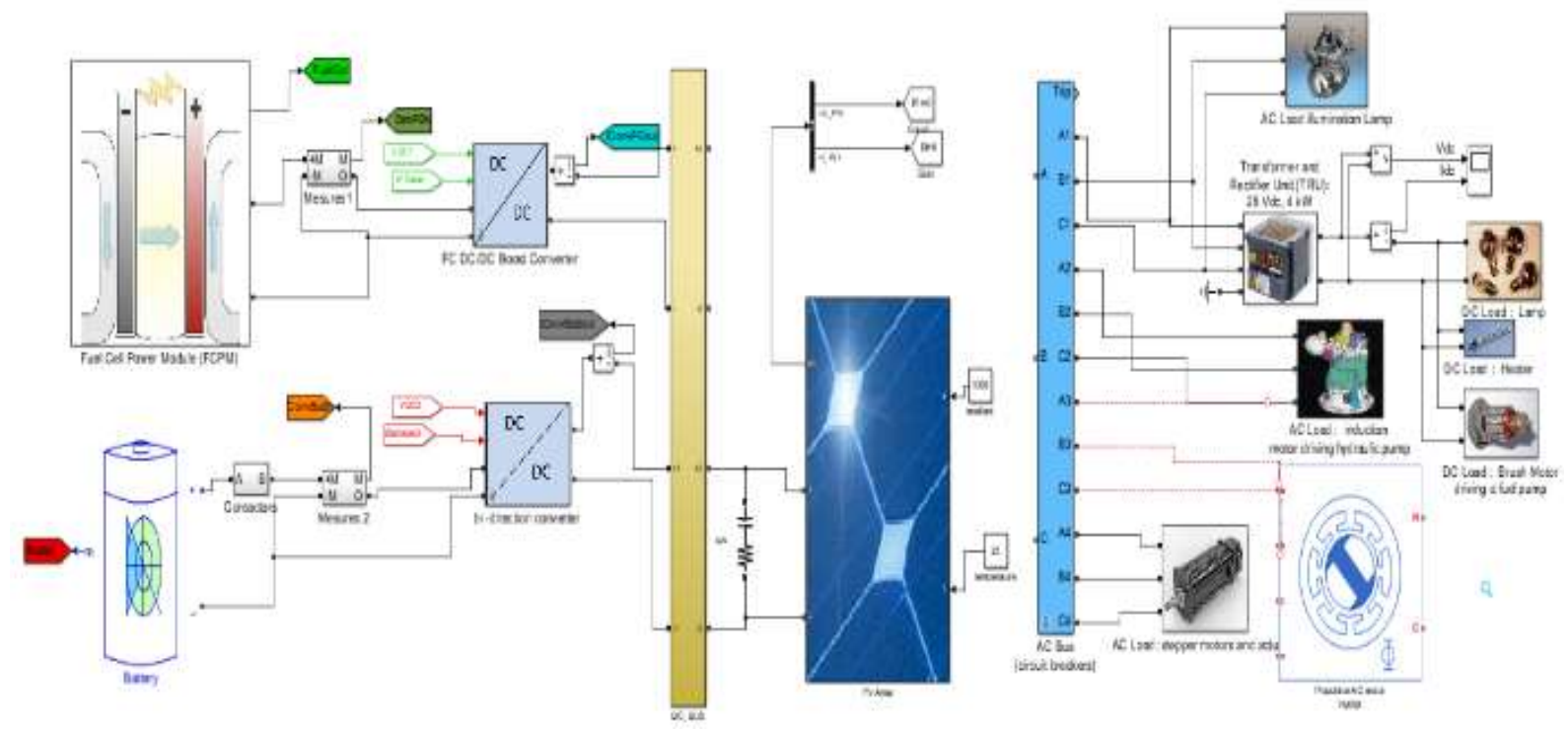

into modules $[18,19]$.

Fig. 1 The Proposed Hybrid System Architecture. 


\section{HYBRID SYSTEM ARCHITECTURE.}

The hybrid power system allows the system to combine two or more energy sources into a hybrid energy system. The other sources will accomplish the drawbacks of any source. The system is designed based on the power and energy required for a typical unique naval ship's mission. That submarine is seeking a mission that required a low acoustic and noise signature. The fuel cell has been identified as the most promising technology for ships, promising in future marine because of its dependability in all marine environmental conditions and ability to work in both low and high temperatures. The disadvantage of the fuel cell is its slow dynamic response. Any renewable energy should be coupled with an energy storage system to overcome the fluctuation from renewable energy resources due to environmental conditions or sudden outages and ensure system stability.

\subsection{Fuel cell /PV Hybrid Energy System.}

A typical fuel cell/battery hybrid system is the famous pre-designed and tested system used in many applications such as an emergency landing cycle, provided by Bombardier Aerospace under the technique of more electric aircraft (MEA) [20]. And in naval ship systems under the strategy all-electric ships (AES) [4].

The proposed hybrid electric power system is shown in Figure 2. consists of the fuel cell system as a D.C. power supply to meet the average demand load $(10 \mathrm{~kW})$, a photovoltaic array is introduced to enhancement the system response with clean, pollution-free energy, no fuel cost, etc., the common problem with these sources is their dependence on the climatic conditions due to which the power produced is unpredictable. The batteries and supercapacitors are designed to assist fluctuation during continuous, transient peak demand and improve the system's power quality. The fuel cell system is a proton exchange membrane (PEM) with 30-60 V 12.5-kW max. Valence battery modules four batteries $(12.8 \mathrm{~V}, 40 \mathrm{Ah})$ are used along with six NESSCAP supercapacitor modules $(48.6 \mathrm{~V}, 88$ F)[20]. The highest level of control should be used, as shown in fig. 2, to divide the system into three subsystems as follows: -

- A DC bus bar system which feeder from the fuel cell, the PVs, and the battery, Two DC/DC converters for discharging (4 kW. boost converter) and charging ( $1.2 \mathrm{~kW}$ buck converter) for the battery system and DC/DC for controlling the fuel cell's output. These converters have an output voltage regulated with current limitation. The P.V. output module controls the voltage level and enabling the PV system according to the light intensity.

- A.C. systems consist of the inverter system and load profile and monitoring, and protection systems. The inverter system consists of (160-320 V) input dc and converts to3X440 V/60-Hz 10-kVA dc/ac output.

- The load consists of variable loads to emulate the ship's loads. Each converter input/output voltage and current sensor and temperature measurement are equipped to control and monitor the inverter. Figure 2, shows the schematic power and control for the overall proposed system. Signal conditioning is achieved through N.I. Data acquisition cards. 


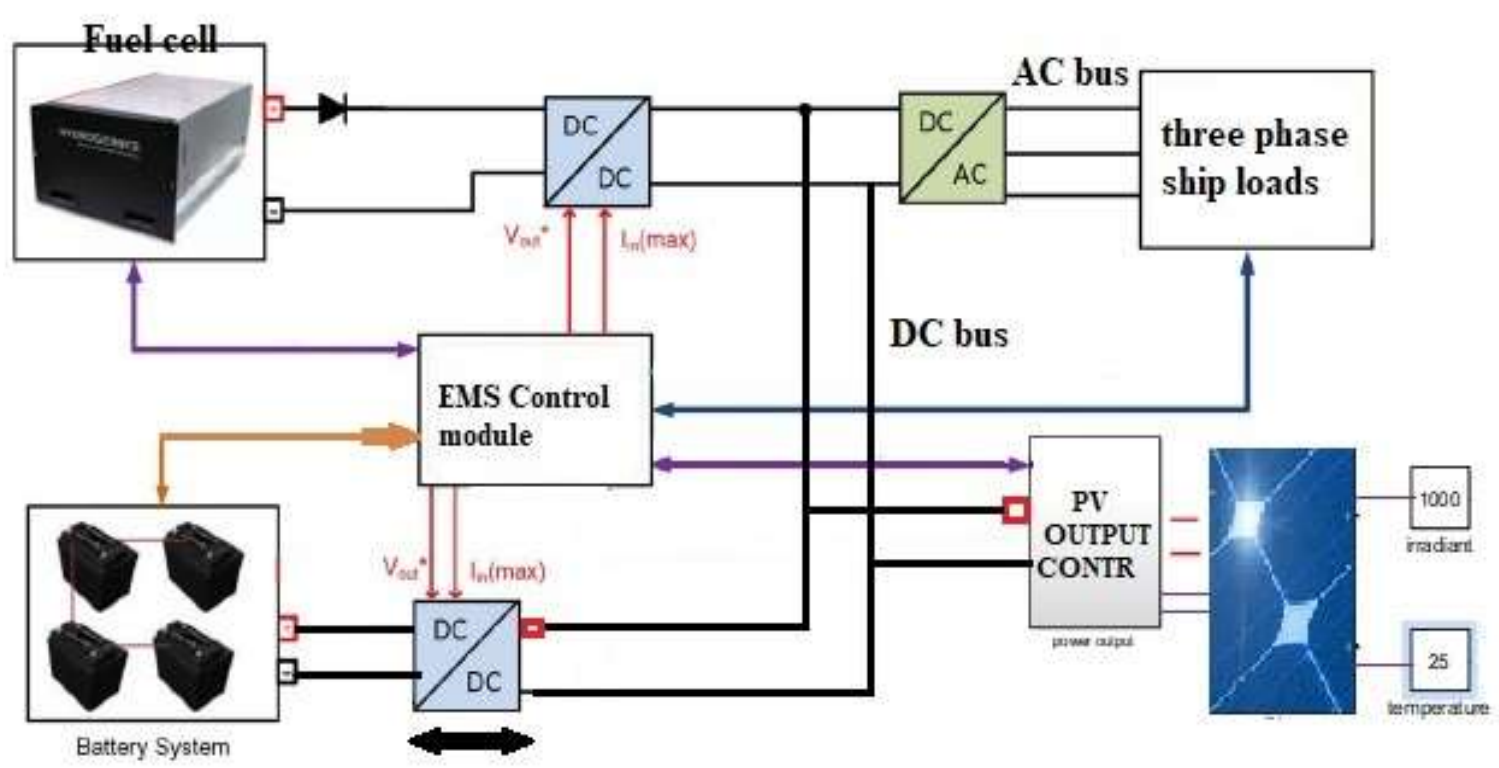

Fig. 2 The schematic diagram for the proposed system.

\subsection{Photovoltaic control modules.}

Connecting the photovoltaic array to ship microgrid need some preparations because the photovoltaic output power not always intermittent. The variety of the environmental conditions during the day and the location in which the ship is sailing. And the variation of the load demand causes shortage or excess in photovoltaic power. Hence, the photovoltaic module is designed with a high level of the control system to identify the best time to operate the photovoltaic module, control the output power, synchronize with the grid (A.C. or D.C.) grid according to the load type, and also connect with the storage system to compensate the photovoltaic output power or to charge storage system in case of excessive power [21].

Photovoltaic module design considers the environmental conditions are constant values of irradiation $\left(1000 \mathrm{~W} / \mathrm{m}^{2}\right) \&$ temperature $\left(25^{\circ} \mathrm{C}\right)$; however, those values not always constants with these values. Therefore, it is necessary to have effective maximum power point tracking (MPPT) for the PV system in addition to the excellent atmospheric condition. The Maximum Power devices have several techniques such as perturbation and observation technique, voltage feedback technique, actual measurement technique, linear approximation technique, incremental conductance technique, and fuzzy logic control technique [22].

Photovoltaic control differs according to the grid-connected type in the case of D.C. grid only voltage level, and power is needed to ensure connected the to the busbar with the same D.C. voltage. For the A.C. grid additional controller to keep synchronized with the three-phase grid (voltage, frequency, phase sequence), PID controller adds Fig. 3 to control active and reactive power produced from the photovoltaic module. 

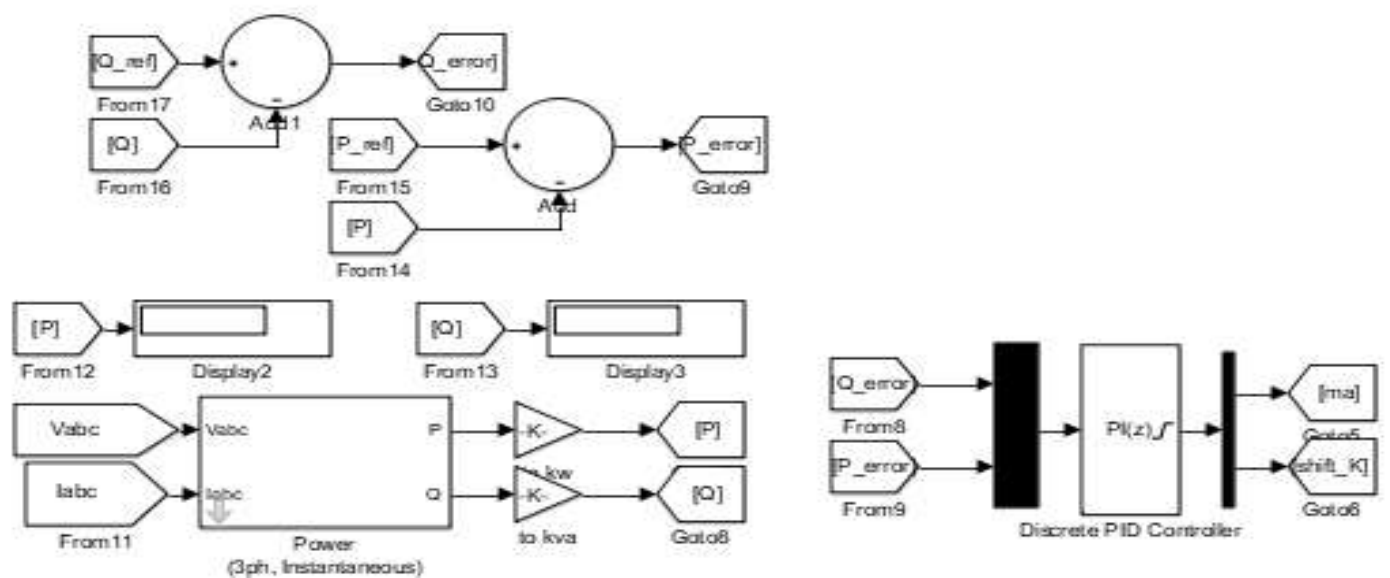

Fig. 3 Active and reactive power control for the PV module.

\section{ENERGY MANAGEMENT STRATEGY.}

The energy management strategy is aimed to ensure the following:

- Reducing the system's energy fluctuations, which is the major problem in renewable energy systems.

- It increases the battery's lifetime by maintaining its state of charge (SoC) in acceptable mode.

- Reduce fuel consumption (hydrogen).

- Produce a maximum amount of solar energy.

- Reduce the amount of energy production by the fuel cell.

This will achieve by using the "artificial neural network" (ANN) technique, one of the artificial intelligence techniques based on training the system to solve the problem depending on the user expert with minimum error.

As shown in fig.4, the system consists of three input the battery state of charge and the load power, and the light intensity to identify which source will produce power, and the two output is the fuel cell power and photovoltaic power.

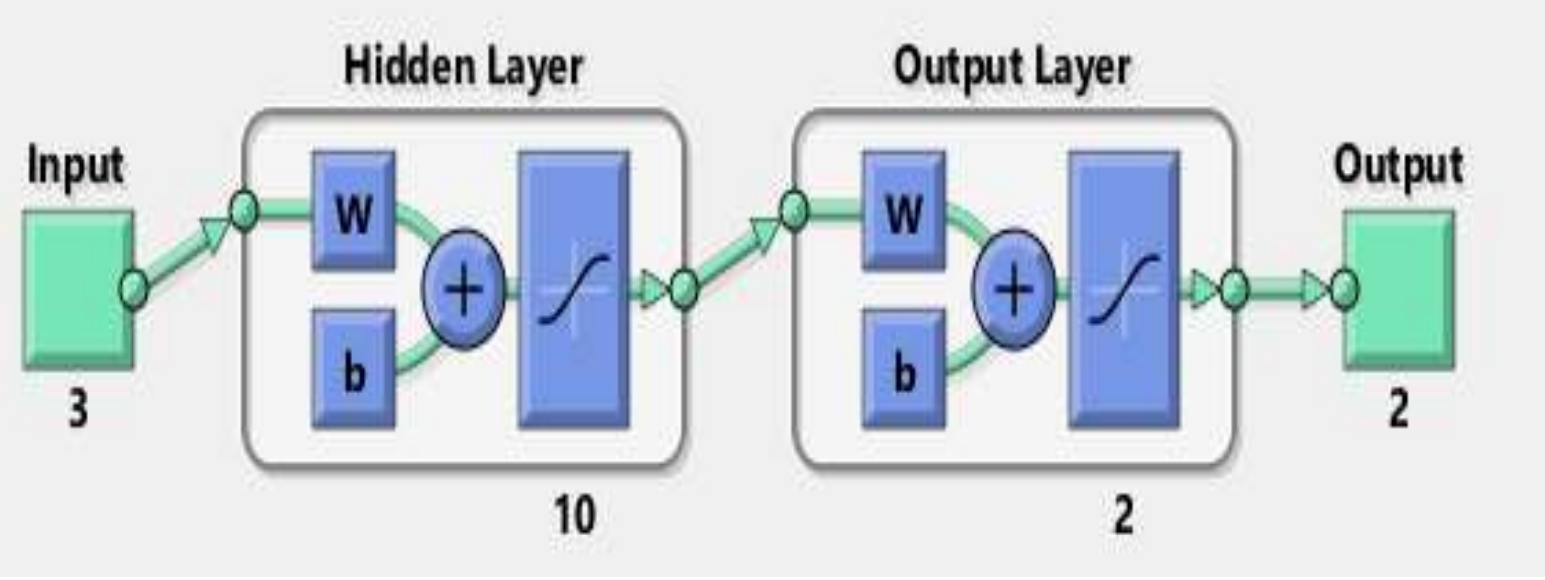

Fig. 4 ANN control structure. 
The ANN control system use (3x1568) input and (2x1568) output data as training data to train the system. As the light intensity is enabled, all power is produced from the photovoltaic module, and when the light intensity is disabling, the power is produced from the fuel cell. The energy management design parameters are shown in the Table.1

Table 1: Energy management designed parameters.

\begin{tabular}{ccc}
\hline parameter & Min & Max \\
\hline Fuel Cell power & $1 \mathrm{~kW}$. & $10 \mathrm{~kW}$ \\
\hline Photovoltaic power & $0 \mathrm{~kW}$. & $10 \mathrm{~kW}$ \\
\hline Battery power & $-1.2 \mathrm{~kW}$ (charging) & $4 \mathrm{~kW}$ (discharging) \\
\hline Battery SoC (high) & $90 \%$ & $100 \%$ \\
\hline Battery SoC (normal) & $60 \%$ & $90 \%$ \\
\hline Battery SoC (low) & $60 \%$ & $40 \%$ \\
\hline D.C. bus voltage & $250 \mathrm{~V}$ & $280 \mathrm{~V}$ \\
\hline
\end{tabular}

\section{SYSTEM OPTIMIZATION PROBLEM.}

Hybrid systems that use at least two energy sources for providing the load with its needed power. that system is usually combined with one or more renewable energy sources, energystoring system, or fuel system that may be the engine with fossil fuel or hydrogen. Hybrid systems are expected to have an optimization technique working with the (EMS) which identifies which source provides the load with its necessary power or how much power should provide for each source to reduce the fuel consumption and ensure the system stability[23],[24],[25].

For achieving this goal, the optimal minimization and control strategy is applied to the hybrid system component fuel cell, supercapacitor, and battery to produce the reference power determined by the EMS based on the load demand[20]. As a result, the electric power produced from the fuel cell and the energy storing system battery and supercapacitor should be converted to equivalent hydrogen consumption.

The calculation of the equivalent of the hydrogen consumption for load $\mathrm{C}$ that is the sum of fuel cell hydrogen consumption $C_{f c}$, battery hydrogen consumption $C_{b a t}$ and solar power from PV $C_{p v}$. The equivalent mathematical problem for minimizing fuel consumption is the following:

$\mathrm{P}_{\mathrm{fc}}=\min \left(\mathrm{C}_{\mathrm{fc}}+\mathrm{k}_{1} \mathrm{C}_{\mathrm{bat}}+\mathrm{k}_{2} \mathrm{C}_{\mathrm{pv}}+\mathrm{k}_{3} \mathrm{C}_{\mathrm{SC}}\right)$

where,

$P_{f c} \quad:$ fuel cell output power

$k_{1}, k_{2}$ and $k_{3} \quad$ : are penalty coefficients converter to hydrogen consumption.

The supercapacitor power is neglected in the optimization problem because the battery converter controls the DC-bus voltage, and the solar power is independent of the hydrogen consumption. And the discharging or charging of the supercapacitors within the same energy from the battery system so the load power is divided between the fuel cell and the battery in each cycle. The optimization problem can be written as:

$\mathrm{x}=\left[\mathrm{p}_{\mathrm{fc}}+\mathrm{k}_{1} \mathrm{P}_{\mathrm{batt}}\right]$ 
To minimize the equation:

$$
F=\left[p_{f c}+k_{1} P_{b a t t}\right] \cdot \Delta T
$$

The battery equivalent hydrogen consumption $C_{\text {bat }}$ can be calculated from the battery power $P_{b a t}$ and the battery SoC Under the equality constraints.

$\mathrm{P}_{\text {load }}=\mathrm{P}_{\mathrm{fc}}+\mathrm{P}_{\text {batt }}$

$$
\mathrm{k}_{1}=1-2 \mu \frac{\left(\mathrm{SoC}-0.5\left(\mathrm{SoC}_{\max }-\mathrm{SoC}_{\min }\right)\right)}{\mathrm{SoC}_{\max }-\mathrm{Soc}_{\min }}
$$

With the boundary constrains

$$
\begin{gathered}
P_{f c \text { min }} \leq P_{f c} \leq P_{f c \text { max }} \\
P_{\text {batt min }} \leq P_{b a t t} \leq P_{\text {batt max }} \\
0 \leq k_{1} \leq 100
\end{gathered}
$$

The above is the system cost function which is a generic problem for any hybrid system consists of fuel cell energy storing devices, and this multi-objective optimization problem was solved for this system in several papers which is not interested in this issue [24], [26], [27].

\section{ANN CONTROL PROCEDURE.}

According to the learning result, the ANN procedure will be carried out from the old trial or human experience. This is the benefit of using ANN, especially at the non-linear systems and the systems need a quick decision in real-time.

Three inputs are entered into the EMS's. The first input is the battery SoC that indicates the amount of power that the battery has; the optimal state is the normal state of charge between $65 \%$ to $85 \%$.
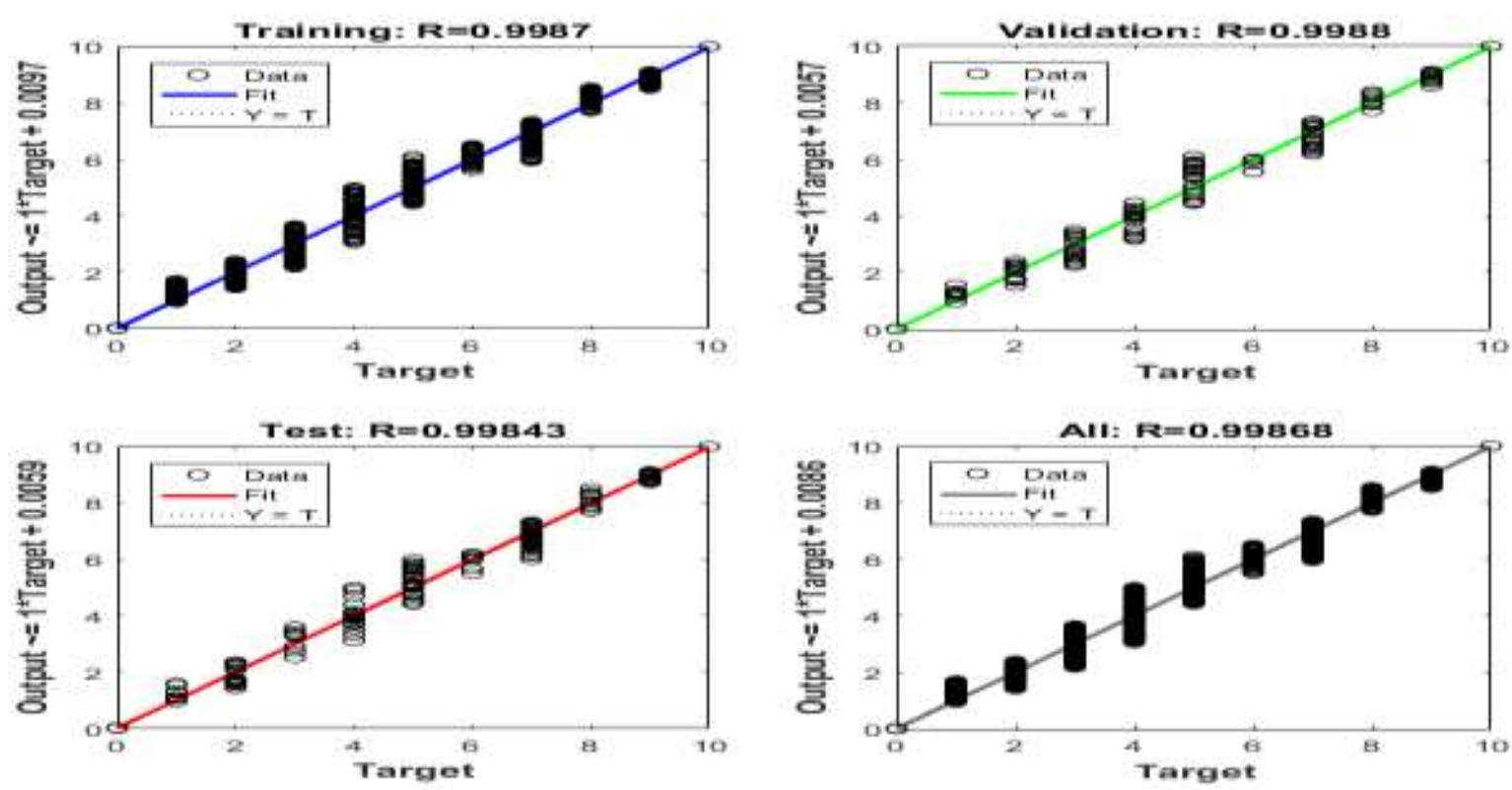

Fig. 5: ANN training regression. 
Another objective is to maintain the battery state of charge (SoC) within the acceptable limits so that the lifetime of the batteries can be increased. Therefore, the second EMS input is the shipload demand. The permissible load between $1-10 \mathrm{~kW}$ indicates the amount of power needed to stabilize the system. The third input to EMS's is the environmental condition that means if it is suitable for the photovoltaic to work or generate the power from the fuel cell.

The system trained with $(5 \times 1568)$ expert data to obtain the best validation performance with a minimum error of less than 0.0013 , as shown in fig. 5 . The system best validation system performance occurs at 443 epochs less than $0.1 \%$ error as shown in Fig.6.

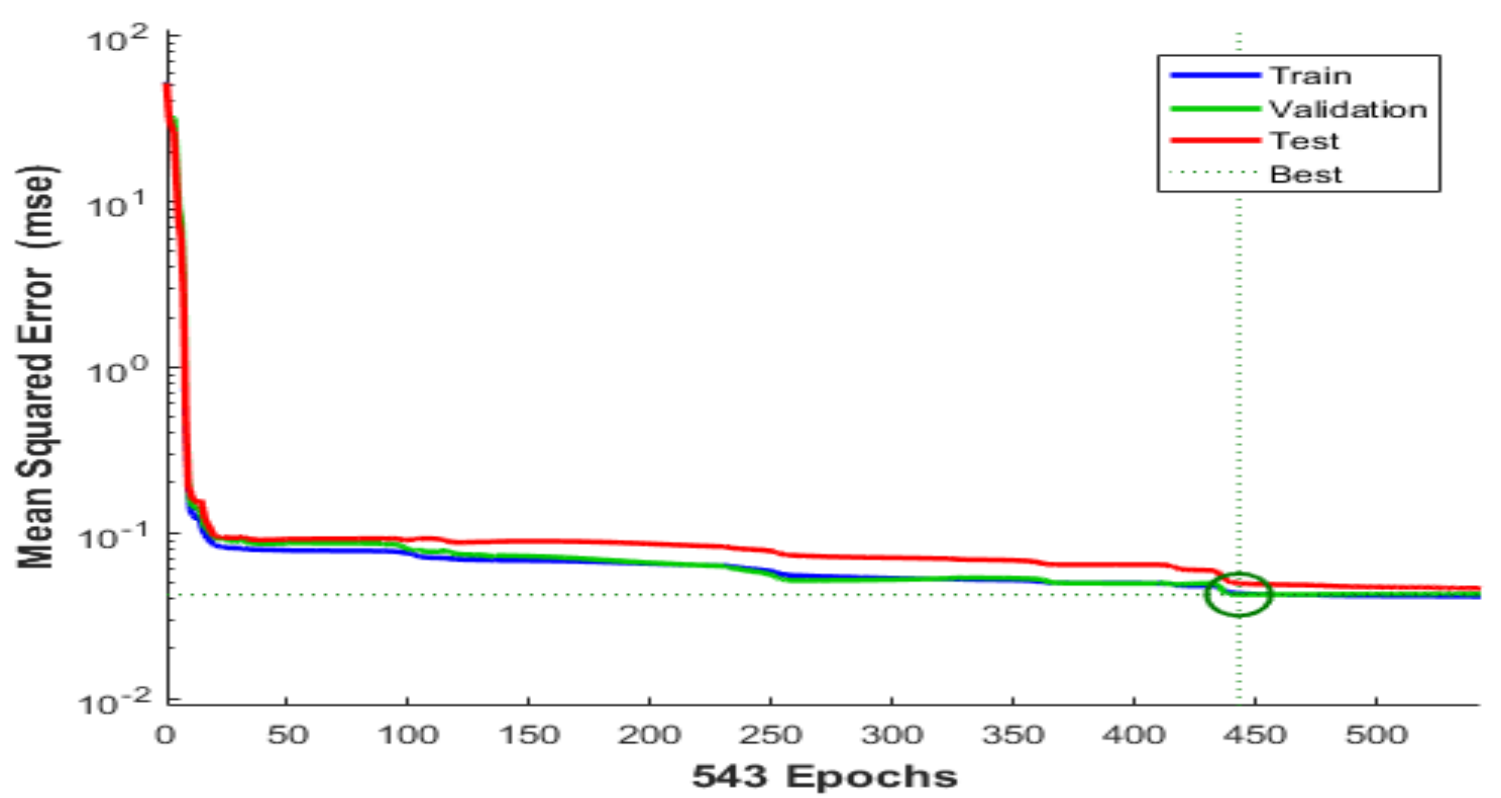

Fig. 6: Best validation system performance.

\section{ANN SIMULATION AND RESULTS.}

The MATLAB simulation results obtained from the energy management system based on the ANN are shown in Table2. For one day sailing during two-period according to the light intensity.

The first column indicates the time during the entire day. The second, third, and fourth columns are the system inputs (battery source, load demand, and the light intensity), the following two columns indicate the predictive power determine by the EMS and which energy source is enabling.

The first period from sunrise at 6 am till dawn at $5 \mathrm{pm}$ in which the solar energy has enabled, and all ship's demand load is provided from the photovoltaic module and safe hydrogen consumed in the fuel cell and the battery.

In the second period, from $6 \mathrm{pm}$ till sunrise, the light intensity is low, so the energy source is generated from the fuel cell and battery according to the demand load.

In case of low light intensity, the fuel cell will provide the load with sufficient power depending on the source, increasing the system's reliability. 
Table 2 Simulation result obtained from EMS based on ANN

\begin{tabular}{|c|c|c|c|c|c|}
\hline \multirow[t]{2}{*}{ Time clock } & \multicolumn{3}{|c|}{ EMS input } & \multicolumn{2}{|c|}{ EMS output } \\
\hline & SoC & Load power & Light intensity & F.C. power & P.V. power \\
\hline 0 & 90 & 5 & 0 & 4.2 & 0 \\
\hline 1 & 80 & 5 & 0 & 4.8 & 0 \\
\hline 2 & 80 & 7 & 0 & 6.8 & 0 \\
\hline 3 & 70 & 6 & 0 & 6.3 & 0 \\
\hline 4 & 60 & 8 & 0 & 8.3 & 0 \\
\hline 5 & 60 & 8 & 0 & 8.3 & 0 \\
\hline 6 & 50 & 8 & 1 & 0 & 8.5 \\
\hline 7 & 60 & 7 & 1 & 0 & 7.6 \\
\hline 8 & 60 & 7 & 1 & 0 & 7.6 \\
\hline 9 & 70 & 9 & 1 & 0 & 9.8 \\
\hline 10 & 80 & 10 & 1 & 0 & 9.8 \\
\hline 11 & 80 & 10 & 1 & 0 & 9.8 \\
\hline 12 & 70 & 11 & 1 & 0 & 10 \\
\hline 13 & 60 & 10 & 1 & 0 & 10 \\
\hline 14 & 60 & 8 & 1 & 0 & 8.4 \\
\hline 15 & 70 & 8 & 1 & 0 & 8.1 \\
\hline 16 & 80 & 5 & 1 & 0 & 4.8 \\
\hline 17 & 90 & 5 & 1 & 0 & 4.4 \\
\hline 18 & 80 & 7 & 0 & 8.6 & 0 \\
\hline 19 & 80 & 9 & 0 & 8.6 & 0 \\
\hline 20 & 70 & 9 & 0 & 8.8 & 0 \\
\hline 21 & 80 & 8 & 0 & 7.7 & 0 \\
\hline 22 & 90 & 6 & 0 & 5.4 & 0 \\
\hline 23 & 90 & 5 & 0 & 4.2 & 0 \\
\hline
\end{tabular}

\section{CONCLUSION.}

The artificial neural network is one of the promising intelligent energy management systems in the ship power system.

These intelligent techniques add flexibility and power to the control and management system when adding/removing any power source or equipment.

Using renewable energy sources in the ship power system has many advantages: reducing greenhouse emissions from ships, reducing the crushing cost by reducing fuel consumption, and increasing system dependability by using more than an energy source in the same power system.

This work is a ring of the chain work that designs a hybrid power system for the ship, enhances its performance by adding a renewable energy source, and implements this intelligent management system in real-time by using Embedded system raspberry Pi to reduce the system cost. 


\section{REFERENCES}

1. S. UNFCCC, "Report of the Conference of the Parties on its twenty-first session, held in Paris from 30 November to 13 December 2015. Addendum. Part two: Action taken by the Conference of the Parties at its twenty-first session."

2. J. Prousalidis, I. K. Hatzilau, P. Michalopoulos, I. Pavlou, and D. Muthumuni, "Studying ship electric energy systems with shaft generator." pp. 156-162.

3. D. Paul, "A History of Electric Ship Propulsion Systems [History]," IEEE Industry Applications Magazine, vol. 26, no. 6, pp. 9-19, 2020.

4. M. Gaber, S. H. El-banna, M. Eldabah and M. S. Hamad, "Model and Control of Naval Ship Power System by The Concept of All-Electric Ships Based on Renewable Energy," 2019 21st International Middle East Power Systems Conference (MEPCON), Cairo, Egypt, 2019, pp. 1235-1240, doi: 10.1109/MEPCON47431.2019.9007914.

5. G. Sulligoi, A. Vicenzutti, and R. Menis, "All-Electric Ship Design: From Electrical Propulsion to Integrated Electrical and Electronic Power Systems," IEEE Transactions on Transportation Electrification, vol. 2, no. 4, pp. 507-521, 2016.

6. A. Vicenzutti, G. Trincas, V. Bucci, G. Sulligoi, and G. Lipardi, "Early-Stage design methodology for a multirole electric propelled surface combatant ship." pp. 97-105.

7. S. Rahman, "Artificial intelligence in electric power systems: a survey of the Japanese industry," IEEE Transactions on Power Systems, vol. 8, no. 3, pp. 1211-1218, 1993.

8. M. K. Dayeni, and M. Soleymani, "Intelligent energy management of a fuel cell vehicle based on traffic condition recognition," Clean Technologies and Environmental Policy, vol. 18, no. 6, pp. 1945-1960, 2016.

9. A. Wangsupphaphol, N. Idris, A. Jusoh, N. Muhamad, and L. W. Yao, "The energy management control strategy for electric vehicle applications." pp. 1-5.

10. H. Ji, O. Alfarraj, and A. Tolba, "Artificial Intelligence-Empowered Edge of Vehicles: Architecture, Enabling Technologies, and Applications," IEEE Access, vol. 8, pp. 61020-61034, 2020.

11. D. Phan, A. Bab-Hadiashar, C. Y. Lai, B. Crawford, R. Hoseinnezhad, R. N. Jazar, and H. Khayyam, "Intelligent energy management system for conventional autonomous vehicles," Energy, vol. 191, pp. 116476, 2020.

12. H. Hemi, J. Ghouili, and A. Cheriti, "A real time fuzzy logic power management strategy for a fuel cell vehicle," Energy Conversion and Management, vol. 80, pp. 6370, 2014/04/01/, 2014.

13. E. William, M. Manic, and B. Johnson, "Ann relays used to determine fault locations on shipboard electrical distribution systems." pp. 143-147.

14. S. Liu, Y. Sun, L. Zhang, and P. Su, "Fault diagnosis of shipboard medium-voltage DC power system based on machine learning," International Journal of Electrical Power \& Energy Systems, vol. 124, pp. 106399, 2021/01/01/, 2021.

15. A. Mahesh, and K. S. Sandhu, "ANFIS based energy management strategy for PV/Wind/Battery hybrid energy system." pp. 1-5.

16. H. M. Fekry, A. A. Eldesouky, A. M. Kassem, and A. Y. Abdelaziz, "Power Management Strategy Based on Adaptive Neuro Fuzzy Inference System for AC Microgrid," IEEE Access, vol. 8, pp. 192087-192100, 2020.

17. Y. Xie, G. Seenumani, J. Sun, Y. Liu, and Z. Li, "A PC-cluster based real-time simulator for all-electric ship integrated power systems analysis and optimization." pp. 396-401.

18. D. Kumar, and F. Zare, "A comprehensive review of maritime microgrids: System architectures, energy efficiency, power quality, and regulations," IEEE Access, vol. 7, pp. 67249-67277, 2019. 
19. A. Shekhar, L. Ramírez-Elizondo, and P. Bauer, "DC microgrid islands on ships." pp. 111-118.

20. S. N. Motapon, L.-A. Dessaint, and K. Al-Haddad, "A comparative study of energy management schemes for a fuel-cell hybrid emergency power system of more-electric aircraft," IEEE transactions on industrial electronics, vol. 61, no. 3, pp. 1320-1334, 2013.

21. M. Gaber, S. H. El-Banna, M. S. Hamad, and M. El-Dabah, "Performance Enhancement of Ship Hybrid Power System Using Photovoltaic Arrays," 2020 IEEE PES/IAS PowerAfrica, PowerAfrica 2020, 2020, doi: 10.1109/PowerAfrica49420.2020.9219808.

22. A. Chowdhury, S. Samal, T. Rout, and M. K. Maharana, "A Complete Comparison of the two Maximum Power Point Tracking Technique (MPPT) for Photovoltaic systems." pp. 72-76.

23. G. Paganelli, S. Delprat, T. M. Guerra, J. Rimaux, and J. J. Santin, "Equivalent consumption minimization strategy for parallel hybrid powertrains." pp. 2076-2081 vol.4.

24. P. Rodatz, G. Paganelli, A. Sciarretta, and L. Guzzella, "Optimal power management of an experimental fuel cell/supercapacitor-powered hybrid vehicle," Control engineering practice, vol. 13, no. 1, pp. 41-53, 2005.

25. J. P. Torreglosa, F. Jurado, P. García, and L. M. Fernández, "Hybrid fuel cell and battery tramway control based on an equivalent consumption minimization strategy," Control Engineering Practice, vol. 19, no. 10, pp. 1182-1194, 2011/10/01/, 2011.

26. P. García, J. P. Torreglosa, L. M. Fernández, and F. Jurado, "Viability study of a FCbattery-SC tramway controlled by equivalent consumption minimization strategy," International journal of hydrogen energy, vol. 37, no. 11, pp. 9368-9382, 2012.

27. S. Mirjalili, and A. Lewis, "The whale optimization algorithm," Advances in engineering software, vol. 95, pp. 51-67, 2016. 